\title{
Ignacio Chávez Rivera. A paradigm in medicine
}

\author{
Ignacio Chávez Rivera. Un paradigma en la medicina \\ Sergio Trevethan-Cravioto* \\ Teaching Coordination Sub-directorate, Instituto Nacional de Cardiología Ignacio Chávez, Mexico City, Mexico
}

\begin{abstract}
This article summarizes the life of Ignacio Chávez Rivera, one of the six most valuable directors that the National Institute of Cardiology has had "Ignacio Chávez Sánchez," founder of the same and father of the aforementioned. His time in life left a clear example to emulate both in the scientific, academic and teaching as well as in the human, family, social and friendly, which make him in the most outstanding student of Master Chávez. His time in life at the National Academy of Medicine, the National Autonomous University of Mexico, the Interamerican Society of Cardiology, the Mexican Society of Cardiology and the Institute itself, has left an indelible mark on these Institutions. The National Institute of Cardiology bows reverently to the figure of Ignacio Chávez Rivera.
\end{abstract}

Key words: Semblance. Paradigm. Ignacio Chávez Rivera. Mexico.

\section{Resumen}

Este documento sintetiza la vida de Ignacio Chávez Rivera, uno de los seis directores más valiosos que ha tenido el Instituto Nacional de Cardiología Ignacio Chávez Sánchez, su fundador y padre del ahora aludido. Su paso por la vida dejó un claro ejemplo a emular tanto en el ámbito científico, académico y docente como en los aspectos humano, familiar y social que lo convirtieron en el alumno más destacado del maestro Chávez. Su paso por la vida en la Academia Nacional de Medicina, la Universidad Nacional Autónoma de México, la Sociedad Interamericana de Cardiología, la Sociedad Mexicana de Cardiología y el propio Instituto ha dejado huella imperecedera en estas instituciones. El instituto Nacional de Cardiología se inclina reverente ante la figura de Ignacio Chávez Rivera.

Palabras clave: Semblanza. Paradigma. Ignacio Chávez Rivera. México.

All of us who had the privilege of being acquainted with the illustrious Mexican (Fig.1) who, among many other things, left us as a heritage the National Institute of Cardiology, which today proudly bears his name, consider a privilege working in it and certainly we feel the heirs to this glorious tradition that implicitly bears the mandate to carry on with it, which is something that has been going on throughout the years since the foundation of the institute in 1944 and until these days. However, the supreme paradigm of complying with this mandate occurred in an unusual form in the person of Ignacio Chávez Rivera, the professor's own son and one of the six directors the institute has had.

\section{Correspondence:}

*Sergio Trevethan-Cravioto

E-mail: trevethan@ cardiologia.org.mx

Available online: 09-02-2020

Date of reception: 22-02-2019

Date of acceptance: 23-07-2019

DOI: 10.24875/ACME.M20000086
Arch Cardiol Mex (Eng). 2020;90(1):77-80

www.archivoscardiologia.com 2604-7063 / @ 2019 Instituto Nacional de Cardiología Ignacio Chávez. Published by Permanyer. This is an open access article under the CC BY-NC-ND license (http://creativecommons.org/licenses/by-nc-nd/4.0/). 


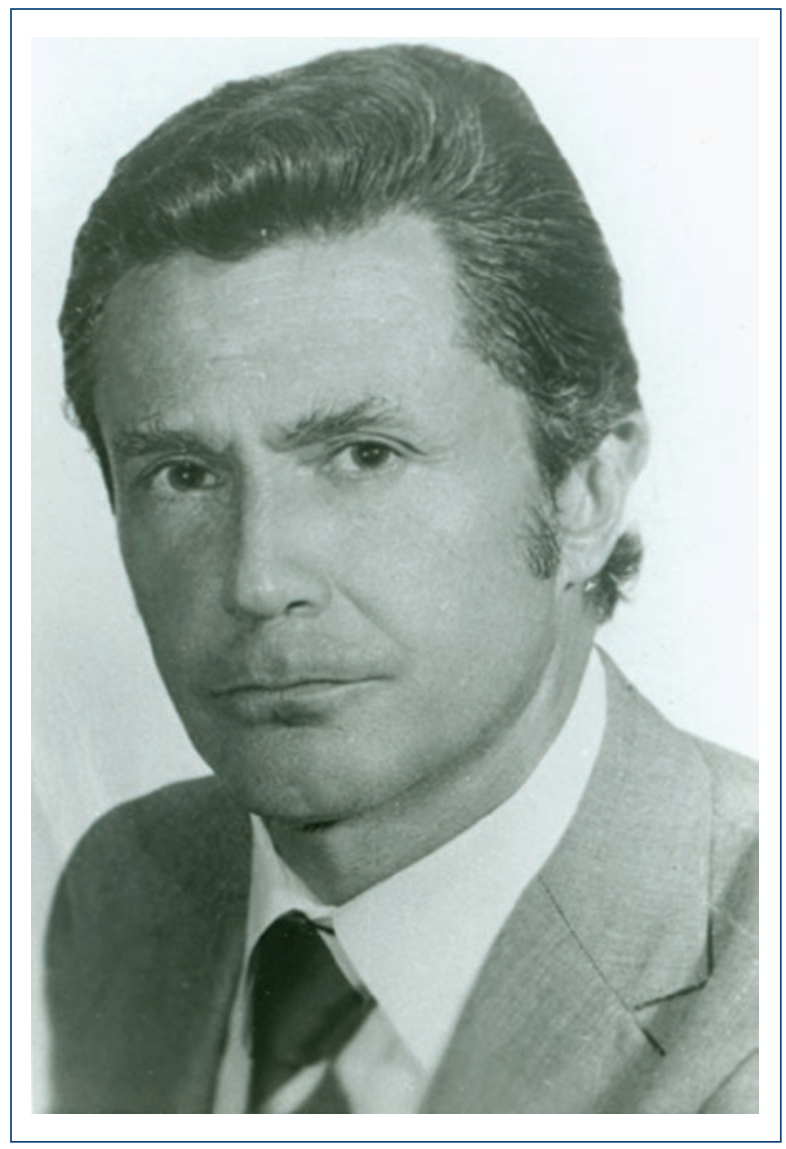

Figure 1. Dr. Ignacio Chávez Rivera

On other occasions, where for some reason I have had to take the floor to describe the trajectory and personality of some celebrity, I have always pointed out that my relationship with him or her was devoid of any personal attachment and that, consequently, I spoke only of the value of the person. This is not the case when I refer to Dr. Ignacio Chávez Rivera; a feeling of solid affection, deep and indestructible, binds me to this man, based on the recognition that I owe him almost everything I am, which is not much, but that for me it is everything and that derives not from the advice, but from the example he gave me (without him having noticed and without ever being his intention) with his life trajectory, through a long period sharing experiences throughout 43 years, a period during which I have tried to follow his quiet nobility.

As I once wrote ${ }^{1}$, Ignacio Chávez Rivera is without a doubt the best of all disciples Ignacio Chávez Sánchez had (who were many and highly valuable).

Distinguished personalities, such as Doctors Jesús Kumate, Guillermo Soberón, Bernardo Fishleder, Daniel
Cosío Villegas, Pierre Duchosal, Antonio Bayes de Luna, José Narro, Juan Ramón de la Fuente, Adolfo Martínez Palomo, and many others, have spoken and written about the greatness of Chávez Jr. work and the modesty it was handled with.

In his medical career, after the surgeon degree obtained at the National Autonomous University of Mexico in 1952, he developed as an internist at the National Institute of Medical Sciences and Nutrition Salvador Zubirán where he was a resident, and was trained as a cardiology resident in the National Institute of Cardiology between 1954 and 1956; subsequently he was a Research Fellow at Harvard University in Massachusetts General Hospital in Boston in 1957 and later on at the Peter Bent Brigham Hospital from 1958 to 1959.

From an early age, Ignacio Chávez Rivera's scientific production began to bear fruit in numerous publications and in the creation of great cardiology works that have been left for posterity: Comma, Syncope and Shock, a 400-page book published in 1969 with reissues in 1974 and $1976^{2}$, Pathophysiological and Clinical Cardiopulmonology of $1973^{3}$, a "titanic and encyclopedic" work in two volumes with 2,000 pages and considered worldwide as a work of mandatory and fundamental consultation in matters of cardiology, Ischemic Heart Disease Due to Coronary Ateroesclerosis ${ }^{4}$, a book of 518 pages published in 1979 and reissued in 1982, Essential Arterial Hypertension ${ }^{5}$ of 1984 and reissued in 1985, a 300-page book, Coronary Heart Disease and Myocardial Ischemia ${ }^{6}$ of 1989 , and Cardiology ${ }^{7}$, two volumes of 1,600 pages published in 1993.

In Ignacio Chávez Rivera's work, academicism stands out fundamentally. In his ascending career, he was distinguished as Deputy Chief of resident physicians at the National Institute of Cardiology in 1955 and Chief of resident physicians in 1956. From Physician Associate, Head of Clinical Department, to Head of the Teaching Division and even General Director of the Institute in two renewed periods from 1989 to 1999 . He had more than 300 participations as a guest speaker in Mexico City, 100 more across the entire Mexican Republic and in 10 American and European countries. Numerous presentations in Congresses and Medical Conferences, 30 articles of clinical research, 66 proofof-concept or diffusion papers and other 200 on various topics. He appears as a co-author in six books. He was Secretary Treasurer of the Inter-American Society of Cardiology and President of the Mexican Society of Cardiology, which later appointed him as a honorary member. In addition, his great skills and fondness for 
drawing led him to collaborate on the excellent book of medical illustrations by Frank $\mathrm{H}$. Netter ${ }^{8}$.

He was president of the second governing board of the Mexican Council of Cardiology; associate member by invitation or honorary member in 15 medical societies in different countries; he was member of the National Academy of Medicine since 1970; secretary of it in 1971, and its president in 1985.

Within our National Autonomous University of Mexico, Dr. Chávez had an outstanding performance, from professor of the cardiology subject, professor by opposition and postgraduate program associate professor to member of the governing board of said study center from 1985 to 1997.

Of modest life despite the surrounding environment and having been born in the bosom an illustrious and already well-known family in the intellectual and social Mexican world of the first half of last century, and unlike that which frequently occurs, Ignacio Chávez Rivera was not unfavorably affected by all this; on the contrary, it further confirmed his idea of being reserved, far from conceit and praise, and especially from self-praise, which is so commonly observed in the present.

In Ignacio Chávez Rivera, as in no other Professor Ignacio Chávez Sánchez disciples, values such as honesty, modesty, decency and loyalty are lived, always connecting (as the Professor himself used to point out) action and thought.

In Ignacio Chávez Rivera, the popular Spanish saying that goes "There is no preacher like Brother example", is also verified, as a proof of what his actions and behavior are. Being the director of the Institute, his modest car was never parked in the place reserved for the management, but in the general parking lot. Or, having a private dining room for the management members, he always preferred eating in the general dining accompanied accompanied by other doctors, assistants, residents, nurses and even by the rest of the administrative or janitorial personnel.

Sometimes, his natural modesty was mistaken or misunderstood by some as lack of character or shyness, especially by those who had a smaller intellectual size than his.

There is no greater burden a man can carry on his back for a lifetime than that of being the son of one of the most illustrious men our country has had and, at the same time, practicing the same profession as the father. Dr. Chávez quietly, calmly and serenely fulfills his mission in life, bearing this huge cross on his shoulders, with great internal pride, yes, but never taking advantage of privileges, benefits or sinecures that the fact of being the son of such an important man might have bestowed him, but with daily, careful and dedicated work, inspired by the humanism that was bequeathed to him.

Let us not misunderstand by any means any discredit my words might suggest for Professor Chávez Sánchez excellence, who in addition to all his virtues and qualities, as Bertrand Russell would say, had a quality called brightness; however, it should be noted that the times that Chávez Sr. and Chávez Jr. lived in are completely different, just like the opportunities for transforming their fields of action. In the Mexico of Chávez Sr. years, Post-Revolution was barely flourishing, and with it a plethora of honest, well-intentioned intellectuals, who formed the group of his first friends in Morelia, honoring the old saying that "birds of a feather flock together", as well as other subsequent friends such as the founders of the National College.

Among the achievements of the National Institute of Cardiology of Chávez Sr. times (as he himself used to point out), there was certain governance autonomy that was allowed, despite being a government branch of the Ministry of Health of the Mexican Republic federal government, which Chávez Jr. administration did no longer enjoy and, on the contrary, the world of Chávez Jr. is plagued by overpopulation, poverty, corruption, social need all around and disproportionate criminality, all coupled with government institutions excessive bureaucratization. In current Mexico, people don't want to be, they just want to have at the expense of anything.

Yesteryear values have been replaced. Child mortality has significantly decreased and, similarly, life expectancy for the elderly has been unusually prolonged; every time more are being born and less are dying, while the size of the bread loaf appears to be the same and very few contribute to make it grow. It is probable that the scientific society of a not too distant future and the religious institutions seriously rethink this and on the right to have as many children as nature and unconsciousness decide.

Chávez Rivera left a huge wealth of academic production to the new generations, which surpassed by far the academic work written by his father and that, in the case of those of us who write, even on a very small scale, know well the effort, dedication and work this entails.

His multiple qualities remarkably include good education and decency and in a very prominent form, his ability to know the background of different personalities, a capability that allowed, in his administrations as director of our home and as president of the Academy of Medicine or on the Governing Board of our university, delegating different responsibilities in men that were ideal for each task, without nepotisms, without mimicry, 
with no favoritism, no falsehood and, especially, with no rhetoric.

His concept of the family is also enviable, as well as his fidelity, loyalty and example, which he transmitted to his children. The decisions Chávez Rivera made were never rushed, never arbitrary and never without prior reflection. In Ignacio Chávez Rivera's life, his great companion of a lifetime, Ofelia de la Lama de Chávez prominently stands out, a brilliant woman of acute intellect, broad and selected culture, but above all, positive attitude in life, especially in adversities. Both personalities, that of Chávez and Ofelia's, complemented each other and crystallized in a beautiful family of cultured and prominent professionals.

Ignacio Chávez Rivera's passage through life was impeccable and his moral value imperishable; those of us who had the fortune of being close to him, without any doubt enriched our spirit, our morals and our culture.

But further, if there is something worthy of admiration and respect in Chávez life, it is his absolute congruence, according to the precepts dictated by his father of merging action and thought. Professor Ignacio Chávez Rivera more than fulfilled the promise made to his father of carving himself alone a name of his own in medicine and society.

Professor Ignacio Chávez Rivera, esteemed and undeserved friend, I salut you.

Sergio Trevethan Cravioto

Deputy Director, Teaching Coordination, Instituto Nacional de Cardiología Ignacio Chavez.

\section{Funding}

No funding was received for writing this article.

\section{Conflict of interests}

The author declares that he has no conflicts of interest.

\section{Ethical disclosures}

Protection of people and animal subjects. The authors declare that no experiments were performed on humans or animals for this study.

Confidentiality of data. The authors declare that no patient data appear in this article.

Right to privacy and informed consent. The authors declare that no patient data appear in this article.

\section{References}

1. Trevethan-Cravioto $S$. Ignacio Chávez y la Escuela Cardiológica Mexicana e Internacional: el pensamiento médico contemporáneo. En Uribe-Elías R (coord.). Aguascalientes: Universidad Autónoma de Aguascalientes, 2007:81-98.

2. Chávez- Rivera I. Coma, síncope y shock. Ciudad de México: Francisco Méndez Otero, editor y distribuidor, sucursal Mérida, 1969.

3. Chávez-Rivera I. Cardioneumología fisiopatológica y clínica. Ciudad de México: Dirección General de Publicaciones, Universidad Nacional Autónoma de México. Ciudad Universitaria, 1973.

4. Chávez Rivera I. Cardiopatía isquémica por aterosclerosis coronaria Ciudad de México: Salvat Mexicana de Ediciones, 1978.

5. Chávez-Rivera I. Hipertensión arterial esencial. Ciudad de México: Ediciones Crossiere, 1985.

6. Chávez Rivera I. Cardiopatía coronaria e isquemia miocárdica. Ciudad de México: McGraw-Hill-Interamericana, 1989.

7. Chávez-Rivera I Cardiología. Ciudad de México: Lito Arte, 1993.

8. Netter F. The Ciba Collection of Medical llustrations. Vol. 5 Heart. New Jersey: 1978. 